\title{
The Metabolism of Acetamidothiazoles in the Rat
}

\section{2-ACETAMIDO-4-CHLOROMETHYLTHIAZOLE}

\author{
By D. H. CHATFIELD and W. H. HUNTER \\ Lilly Research Centre, Erl Wood Manor, Windlesham, Surrey, U.K., and Department of Pharmacy, \\ Chelsea College, University of London, Manresa Road, London SW3 6LX, U.K.
}

(Received 4 December 1972)

\begin{abstract}
2-Acetamido-4-chloromethylthiazole is metabolized in the rat to (2-acetamido-4-thiazolylmethyl)mercapturic acid and 2-acetamidothiazole-4-carboxylic acid. 2-Acetamido4-methylthiomethylthiazole and the corresponding sulphoxide and sulphone are also produced as minor metabolites. The identification of the metabolites is described and their formation investigated. Quantitative results on the excretion of the metabolites labelled with ${ }^{14} \mathrm{C}$ are reported.
\end{abstract}

In the preceding paper we described studies on the metabolism and excretion, by the rat, of some 4substituted 2-acetamidothiazoles (Chatfield \& Hunter, 1973). These compounds were part of a series of anti-inflammatory compounds (Evans, 1972) of which the most active member was the 4-chloromethyl compound (I). The metabolic fate of this compound was therefore of interest and particularly the extent to which the reactive chloromethyl group might act as the centre for metabolic attack.

All the acetamidothiazoles that we had previously investigated were metabolized by extensive fission and degradation of the thiazole ring but none of them contained a chemically reactive group.

\section{Materials and Methods}

The reagents used, the extraction methods, the radioisotope methods and spectroscopic methods were as described by Chatfield \& Hunter (1973).

T.l.c. was conducted on $20 \mathrm{~cm} \times 20 \mathrm{~cm}$ plates, 0.25 or $2.00 \mathrm{~mm}$ thick, coated with silica gel $\mathrm{G}$, fluorescent (E. Merck, Darmstadt, Germany). Plates were developed for $15 \mathrm{~cm}$ in benzene-methanol $(9: 1, \mathrm{v} / \mathrm{v})$ $R_{F}$ values are shown in Table 1 .

Sulphur-containing compounds were detected in t.l.c. by the method described by Knight \& Young (1958). Thiols were detected by spraying the plates with $\mathrm{N}$-ethylmaleimide (Block et al., 1958). Sulphoxides were detected with hydriodic acid-starch reagent (Thompson et al., 1963) and the amino acids and aminothiazoles with ninhydrin reagent $(0.5 \%$, $\mathrm{w} / \mathrm{v}$ in acetone).

\section{Preparation of compounds}

2-Acetamido-4-chloromethyl[2-14C]thiazole (I). This was prepared (Bhargava \& Singh, 1960) from thio $\left[{ }^{14} \mathrm{C}\right]$ urea $(570 \mathrm{mg}, 0.05 \mathrm{mCi})$. The product, yield $970 \mathrm{mg}$, had a specific radioactivity of $15.2 \mu \mathrm{Ci} / \mathrm{g}$ and was $99.2 \%$ radiochemically pure on t.l.c.

$S$-(2-Acetamido-4[2-14 C]thiazolylmethyl)- $\mathrm{N}$-acetylL-cysteine (II). This was prepared by treating sodium $(33 \mathrm{mg})$, ethanol $(15 \mathrm{ml})$ and $N$-acetyl-L-cysteine $(123 \mathrm{mg})$ with 2-acetamido-4-chloromethyl[2-14 $\mathrm{C}$ thiazole (I) $(144 \mathrm{mg})$. The mixture was kept at $20^{\circ} \mathrm{C}$<smiles>[R]c1csc(NC(C)=O)n1</smiles>

(I) $\mathrm{R}=\mathrm{Cl}-\mathrm{CH}_{2}-$

(IV) $\mathrm{R}=\mathrm{HS}-\mathrm{CH}_{2}-$

(VI) $\mathrm{R}=\mathrm{HO}-\mathrm{CH}_{2}-$

(VIII) $\mathrm{R}=\mathrm{Me}-\mathrm{SO}_{2}-\mathrm{CH}_{2}-$<smiles>CC(=O)Nc1nc(CSCC(NC(C)=O)C(=O)O)cs1</smiles>

(II)

(III) $\mathrm{R}=\mathrm{Me}-\mathrm{S}-\mathrm{CH}_{2}-$

(V) $\mathrm{R}=\mathrm{HO}_{2} \mathrm{C}-$

(VII) $\mathrm{R}=\mathrm{Me}-\mathrm{SO}-\mathrm{CH}_{2}-$ 
for $16 \mathrm{~h}$, then the solvent was evaporated and the residue dissolved in $0.1 \mathrm{M}-\mathrm{NaOH}(5 \mathrm{ml})$. The solution was acidified and the product was extracted with ethyl acetate $(4 \times 10 \mathrm{ml})$. Evaporation of the solvent gave a crystalline material that was recrystallized from acetone-water $(3: 1, \mathrm{v} / \mathrm{v})$, yield $150 \mathrm{mg}$, m.p. $230-232^{\circ} \mathrm{C}$. The i.r. spectrum and the n.m.r. spectrum (Table 2) were consistent with the structure (II) proposed for this compound.

The product was $92 \%$ radiochemically pure by t.l.c. and contained $6 \%$ of 2-acetamido-4-hydroxymethyl$\left[2-{ }^{14} \mathrm{C}\right]$ thiazole produced by hydrolysis of the chloromethyl compound.
2-Acetamido-4-methylthiomethylthiazole (III). A solution of sodium $(1.15 \mathrm{~g}, 50 \mathrm{mmol})$ in ethanol $(100 \mathrm{ml})$ was saturated with methanethiol. 2-Acetamido-4-chloromethylthiazole $(9.5 \mathrm{~g}, 50 \mathrm{mmol})$ was added, then the solution was heated under reflux for $3 \mathrm{~h}$. The solvent and excess of MeSH were removed by distillation and the solid residue was crystallized from ethanol, m.p. $120-122^{\circ} \mathrm{C}$, yield $4.1 \mathrm{~g}$ (Found: $\mathrm{C}, 41.7 ; \mathrm{H}, 5.1 ; \mathrm{N}, 13.9 ; \mathrm{C}_{7} \mathrm{H}_{10} \mathrm{~N}_{2} \mathrm{OS}_{2}$ requires $\mathrm{C}$, $41.6 ; \mathrm{H}, 5.0 ; \mathrm{N}, 13.9 \%)$.

2-Acetamido-4-methylsulphinylmethylthiazole(VII). This was prepared by oxidation of compound (III) $(3.4 \mathrm{~g}, 20 \mathrm{mmol})$ in acetic acid $(50 \mathrm{ml})$ with $\mathrm{H}_{2} \mathrm{O}_{2}$

Table 1. $R_{F}$ values, spectral data and \% excretion of 2-acetamido-4-chloromethylthiazole and its metabolites

$R_{F}$ values refer to t.l.c. on silica gel G, fluorescent plates (Merck) 0.25 or $2.0 \mathrm{~mm}$ thick in benzene-methanol $(9: 1, \mathrm{v} / \mathrm{v})$.

\section{Compound}

2-Acetamido-4-chloromethylthiazole (I)

2-Acetamido-4-hydroxymethylthiazole (VI)

2-Acetamido-4-methylthiomethylthiazole (III)*

2-Acetamido-4-methylsulphonylmethylthiazole (VIII)*

2-Acetamido-4-methylsulphinylmethylthiazole (VII)*

$S$-(2-Acetamido-4-thiazolylmethyl)- $N$-acetyl-L-cysteine

(II)

2-Acetamidothiazole-4-carboxylic acid (V)*

$\mathrm{pH}$ of extraction

$\begin{array}{cc}\boldsymbol{R}_{\boldsymbol{F}} \\ - & 0.89 \\ \overline{7.0} & 0.27 \\ 7.0 & 0.81 \\ 7.0 & 0.40 \\ 2.0 & 0.21 \\ & 0.05\end{array}$

2.0 $\lambda_{\text {max. }}$ in water $(\mathrm{nm})$

$\begin{array}{ccc}\text { Neutral } & \text { Alkaline } & \text { \% of dose } \\ 267 & 288 & 0 \\ 269 & 287 & 0 \\ 271 & 290 & 2 \\ 268 & 289 & 2 \\ 269 & 289 & 11 \\ 272 & 290 & 42 \\ 270 & 268 & 18\end{array}$

* Confirmed by identification with authentic specimen.

Table 2. N.m.r. spectra in $\mathrm{C}^{2} \mathrm{HCl}_{3}$ of 2-acetamido-4-chloromethylthiazole and its metabolites

\section{Compound \\ Chemical \\ Exchange Number of with ${ }^{2} \mathrm{H}_{2} \mathrm{O}$ protons}

2-Acetamido-4-chloromethylthiazole (I) shift $(\tau)$

\subsection{5}

5.49

3.11

2-Acetamido-4-methylthiomethylthiazole (III)

\subsection{3}

7.76

6.32

3.25

$S$-(2-Acetamido-4-thiazolylmethyl)- 8.13 $N$-acetyl-L-cysteine (II)
7.87

$7.1-7.4$

6.25

5.59

3.07

1.85

$5.70+1.66$

Multiplicity
Singlet
Singlet

Singlet

Singlet

Singlet

Singlet

Singlet

Singlet

Singlet

Doublet

Singlet

Multiplet

Singlet

Doublet

Broad

\section{None}

None

None

None

None

None

None

None

None

None

None

Triplet

None

Rapid

Rapid

\section{Assignment}

- $\mathrm{CO}-\mathrm{Me}$

$-\mathrm{CH}_{2} \mathrm{Cl}$

H“l

Me-S-

-CO-Me

$-\mathrm{X}-\mathrm{CH}_{2}-$

H少

-CO-Me

- $\mathrm{CO}-\mathrm{Me}$

$-\mathrm{CH}_{2}-\mathrm{S}-$

$-\mathrm{CH}_{2}-\mathrm{S}-$

¿CH-

1 H

1 -NH-CO-

$2>\mathrm{NH}$ and $-\mathrm{CO}_{2} \mathrm{H}$ 
$(2.35 \mathrm{ml}$ of $30 \% \mathrm{w} / \mathrm{v}, 20 \mathrm{mmol})$ for $48 \mathrm{~h}$ at $20^{\circ} \mathrm{C}$. The unchanged $\mathrm{H}_{2} \mathrm{O}_{2}$ was removed by $\mathrm{SO}_{2}$ and the residue was crystallized from ethanol-light petroleum (b.p. 60-80 $\left.{ }^{\circ} \mathrm{C}\right)(9: 1, \mathrm{v} / \mathrm{v})$ m.p. $159-161^{\circ} \mathrm{C}$ (Found: C, $38.9 ; \mathrm{H}, 4.9 ; \mathrm{N}, 12.8 ; \mathrm{C}_{7} \mathrm{H}_{10} \mathrm{~N}_{2} \mathrm{O}_{2} \mathrm{~S}_{2}$ requires $\mathrm{C}, 38.5$; $\mathrm{H}, 4.6 ; \mathrm{N}, 12.8 \%$ ).

2 - Acetamido - 4 - methylsulphonylmethylthiazole (VIII). This was prepared similarly, from compound (III) $(3.4 \mathrm{~g}, 20 \mathrm{mmol})$, acetic acid $(50 \mathrm{ml})$ and $\mathrm{H}_{2} \mathrm{O}_{2}$ $(12 \mathrm{ml}$ of $30 \% \mathrm{w} / \mathrm{v}, 100 \mathrm{mmol})$. The product, a mixture of the sulphone (VIII) and the corresponding $\mathrm{N}$-oxide, was crystallized three times from methanol to give pure compound (VIII), m.p. $205-206^{\circ} \mathrm{C}$, yield $1.0 \mathrm{~g}$ (Found: $\mathrm{C}, 36.1 ; \mathrm{H}, 4.5 ; \mathrm{N}, 12.1$; $\mathrm{C}_{7} \mathrm{H}_{10} \mathrm{~N}_{2} \mathrm{O}_{3} \mathrm{~S}_{2}$ requires $\mathrm{C}, 35.9 ; \mathrm{H}, 4.3 ; \mathrm{N}, 12.0 \%$ ). 2-Acetamidothiazole-4-carboxylic acid was prepared as described by Traumann (1960) and 2-acetamido4-hydroxymethylthiazole as described by Chatfield \& Hunter (1973).

\section{Reverse isotope-dilution analysis}

Urine $(2 \mathrm{ml})$ containing 2 -acetamido $\left[2-{ }^{14} \mathrm{C}\right]$ thiazole-4-carboxylic acid formed metabolically from 2-acetamido-4-chloromethyl $\left[2-{ }^{14} \mathrm{C}\right]$ thiazole was diluted 1:5 with water and authentic 2-acetamidothiazole-4-carboxylic acid $(500 \mathrm{mg})$ was added. The suspension was warmed to $60^{\circ} \mathrm{C}$ and the acid was dissolved by addition of $5 \mathrm{M}-\mathrm{KOH}$. The solution was cooled and the carboxylic acid precipitated by addition of $5 \mathrm{M}-\mathrm{HCl}$. The precipitate was filtered off, washed with $0.1 \mathrm{M}-\mathrm{HCl}(5 \times 2 \mathrm{ml})$ and the dissolution, precipitation and filtration steps were repeated twice more. The sample of acid was dried in vacuo and its specific radioactivity was determined as $28.0 \mathrm{nCi} / \mathrm{g}$. It was then crystallized from ethanol-dimethylformamide $(3: 1, v / v)$ and had a specific radioactivity of $29.8 \mathrm{nCi} / \mathrm{g}$.

\section{Glutathione conjugation studies}

These were conducted by incubating the appropriate substrates $(3 \mathrm{~mm}$ in $0.2 \mathrm{ml}$ of ethanol) with GSH (5 mM) and soluble liver fraction $(2.0 \mathrm{ml})$ made up to $6.0 \mathrm{ml}$ with sodium-potassium phosphate buffer (pH8.0). Incubation was conducted for $1 \mathrm{~h}$ at $37^{\circ} \mathrm{C}$ and then terminated by addition of acetic acid $(1.0 \mathrm{ml})$.

Control incubations were run from which GSH, substrate or liver fraction were omitted. In other experiments GSSG, L-cysteine or $N$-acetyl-L-cysteine replaced GSH.

The organic materials were adsorbed from the solutions with charcoal $(75 \mathrm{mg})$ and eluted with $10 \mathrm{ml}$ of methanol-benzene- $\mathrm{NH}_{3}$ (sp.gr. 0.880$)(90: 7: 3$, by vol.). The eluate was evaporated and the residue chromatographed by t.l.c. on silica gel in butan-1-olacetic acid-water (12:1:2, by vol.).

\section{Isolation of metabolites}

2-Acetamido-4-chloromethylthiazole was administered intraperitoneally to four male Lodgemoor Wistar rats $(200 \mathrm{~g})$ for 3 days at a daily dose of $100 \mathrm{mg} / \mathrm{kg}$. Urine was collected over $72 \mathrm{~h}$ and extracted at $\mathrm{pH} 7$ and at $\mathrm{pH} 2$, with ethyl acetate. The neutral extract contained three metabolites and two further metabolites were in the acidic extract. T.l.c. and u.v. data for these are in Table 1.

The neutral metabolites were isolated by chromatography on a silica gel column eluted with benzenemethanol $(3: 1, v / v)$ which was gradually changed to $100 \%$ methanol. Preparative t.l.c. as in Table 1 gave pure samples of the metabolites.

The metabolites from the acid extraction were separated by ion-exchange chromatography on Permutit Zeo-Carb 225 cation-exchange resin (Chatfield \& Hunter, 1973) to give white needles that were crystallized from methanol-water $(3: 1, v / v)$, yield $27 \mathrm{mg}, \mathrm{m} . \mathrm{p} .230^{\circ} \mathrm{C}$ decomp. The other metabolite was purified by preparative t.l.c. on silica gel eluted with butan-1-ol-acetic acid-water (12:1:2, by vol.), $R_{F} 0.32$.

The relative proportions of the metabolites were established by administration of 2-acetamido-4chloromethyl $\left[2-{ }^{14} \mathrm{C}\right]$ thiazole to rats as single doses of $100 \mathrm{mg} / \mathrm{kg}$ orally, intraperitoneally or subcutaneously.

\section{Results}

2-Acetamido-4-chloromethylthiazole was rapidly absorbed by rats, $75 \%$ of the dose appearing in the urine and $10 \%$ in the faeces in the first $24 \mathrm{~h}$. A further $7 \%$ of the dose appeared over the next $72 \mathrm{~h}$. There was no evidence of ${ }^{14} \mathrm{CO}_{2}$ in the exhaled air.

A similar pattern of excretion was observed after administration by the intraperitoneal and subcutaneous routes.

T.1.c. separation showed that none of the original compound was excreted unchanged and that five metabolites were formed.

The i.r. spectrum of the major metabolite, $R_{F} 0.05$ (Table 1), suggested that it contained a carboxyl group $\left(1850-2600 \mathrm{~cm}^{-1}, 1705 \mathrm{~cm}^{-1}\right)$ and a secondary amide group $\left(1640 \mathrm{~cm}^{-1}\right.$ and $\left.1690 \mathrm{~cm}^{-1}\right)$. The presence of both was verified by the n.m.r. spectrum (Table 2) which indicated that the metabolite was the mercapturic acid conjugate of compound (I). The i.r. spectrum was identical with that of authentic compound (II).

The second metabolite extracted at $\mathrm{pH} 2$ was also a carboxylic acid and was shown by t.l.c., u.v. and i.r. spectra, to be 2-acetamidothiazole-4-carboxylic acid (V). The presence of this acid in the urine was confirmed by reverse isotope-dilution analysis. This showed that compound (V) was indeed a metabolite and over a $24 \mathrm{~h}$ period accounted for $18.7 \%$ of an oral 
dose of $100 \mathrm{mg} / \mathrm{kg}$ of compound (I). The formation of the acid (V) could be accounted for by metabolic oxidation of the alcohol (VI) which, in turn, could be formed by direct hydrolysis of compound (I). When compound (I) was shaken at room temperature in aqueous solution (pH7.4) it was slowly hydrolysed and the formation of increasing proportions of compound (VI) was shown by t.l.c. of extracts (Table 1). The alcohol formed had the same $R_{F}$ value as that of the authentic hydroxymethyl compound (Chatfield \& Hunter, 1973).

The minor metabolite of $R_{F} 0.81$ gave an i.r. spec-

Table 3. Mass spectrum of 2-acetamido-4-chloromethylthiazole compared with that of the 2-acetamido4-methylthiomethylthiazole isolated as a metabolite

2-Acetamido-4-chloromethylthiazole (I)

\begin{tabular}{|c|c|c|c|}
\hline$m / e$ & $\begin{array}{c}\text { Abundance } \\
(\%)\end{array}$ & $m / e$ & $\begin{array}{c}\text { Abundance } \\
\%\end{array}$ \\
\hline 192 & 17.2 & 204 & 2.7 \\
\hline 190 & 45.2 & 202 & 30.5 \\
\hline 156 & 56.9 & 160 & 6.7 \\
\hline 155 & 10.1 & 157 & 8.4 \\
\hline 151 & 5.3 & 156 & 89.2 \\
\hline 150 & 76.8 & 155 & 8.3 \\
\hline 149 & 21.9 & 115 & 9.5 \\
\hline 148 & 100 & 114 & 84.7 \\
\hline 115 & 11.3 & 113 & 81.8 \\
\hline 114 & 24.0 & 71 & 26.3 \\
\hline 113 & 98.4 & 69 & 11.9 \\
\hline 103 & 5.3 & 67 & 18.8 \\
\hline 71 & 27.2 & 61 & 8.2 \\
\hline 69 & 10.0 & 47 & 9.3 \\
\hline 67 & 14.4 & 45 & 56.8 \\
\hline 45 & 36.0 & 44 & 36.3 \\
\hline 43 & 87.2 & 43 & 100 \\
\hline
\end{tabular}

trum very similar to that of the original compound (I) and this, together with the u.v. evidence, suggested that its structure was very similar to that of compound (I). The mass spectrum had a molecular ion $\mathrm{m} / \mathrm{e} 202$, which indicated that the $\mathrm{Cl}$ atom of the parent molecule had been lost in the formation of the metabolite. The $(M+2) / M$ peak ratio was $8.9 \%$ suggesting the presence of two $\mathrm{S}$ atoms in the molecule (Table 3). The fragmentation steps shown in Scheme 1 also indicated the grouping $\mathrm{CH}_{3} \mathrm{~S}-$ in the metabolite and the n.m.r. spectrum (Table 2) confirmed the structure as 2-acetamido-4-methylthiomethylthiazole (III).

The remaining metabolites, $R_{F}$ values 0.40 and 0.21 , were isolated in such small quantity that the i.r. spectra were of poor quality. They did, however, indicate that the amide group had probably been retained and a strong band at $1020 \mathrm{~cm}^{-1}$ in one of the spectra was possibly due to a sulphoxide group.

To isolate larger quantities of these metabolites therefore, two rats were dosed at $100 \mathrm{mg} / \mathrm{kg}$ intraperitoneally with the methylthiomethylthiazole (III). T.l.c. analysis of the urine extracts showed the presence of metabolites at $R_{F}$ values 0.4 and 0.21 . One of these compounds gave a positive spray reaction for a sulphoxide on the chromatographic plate. The i.r. spectrum closely resembled that of compound (III) with the additional band at $1020 \mathrm{~cm}^{-1}$. This band enabled the metabolite to be identified as 2-acetamido-4-methylsulphinylmethylthiazole (VII), confirmed by comparison of the i.r. spectrum with that of an authentic specimen.

The other metabolite, accessible in large quantity by the procedure described above, was identified as the sulphone (VIII) on the basis of the bands present in its i.r. spectrum at $1120 \mathrm{~cm}^{-1}$ and $1325 \mathrm{~cm}^{-1}$. The spectrum was identical with that of an authentic sample of compound (VIII).

No other metabolites were isolated, and extraction of the $24 \mathrm{~h}$ urine sample at $\mathrm{pH} 1$ with butan-1-ol failed to extract any material which gave an aglycone on incubation with $\beta$-glucuronidase.

$$
\begin{aligned}
& \mathrm{Me}-\mathrm{S}-\mathrm{CH}_{2} \|_{\mathrm{S}}^{\mathrm{NH}_{2}} \frac{-42\left(\mathrm{CH}_{2} \mathrm{CO}\right)}{m^{\star} 126.7} \\
& 160 \\
& \mathrm{Me}-\mathrm{S}-\mathrm{CH}_{2} \|_{\mathrm{S}} \underset{\mathrm{NH}-\mathrm{CO}-\mathrm{Me}}{\stackrel{-46\left(\mathrm{CH}_{2} \mathrm{~S}\right)}{m^{\star} 120.5}} \\
& 202 \\
& \stackrel{+}{\mathrm{C}} \mathrm{H}_{2}-\underset{\mathrm{S}}{\|} \mathrm{NH}-\mathrm{CO}-\mathrm{Me} \stackrel{-42\left(\mathrm{CH}_{2} \mathrm{CO}\right)}{m^{\star} 88.3}
\end{aligned}
$$

Scheme 1. Fragmentation pathway of 2-acetamido-4-methylthiomethylthiazole

Detection of a metastable ion is represented by $m^{*}$. The $m / e$ values are indicated in the scheme. 
Table 4. Metabolites of S-(2-acetamido-4[2-14 C]thiazolymethyl)-N-acetyl-L-cysteine (II) on administration to rats at $100 \mathrm{mg} / \mathrm{kg}$ orally

$\boldsymbol{R}_{\boldsymbol{F}}$ values refer to t.l.c. on silica gel $\mathrm{G}$, fluorescent plates (Merck), $0.25 \mathrm{~mm}$ thick in butan-1-ol-acetic acid-water (12:1:2, by vol.).

$\begin{array}{lcc}\quad \text { Metabolites of compound (II) identified } & \boldsymbol{R}_{\boldsymbol{F}} & \text { \% of dose } \\ \text { Unchanged compound (II) } & 0.47 & 47 \\ \text { 2-Acetamido-4-methylthiomethylthiazole (III) } & 0.89 & 1 \\ \text { 2-Acetamido-4-methylsulphonylmethylthiazole (VIII) } & 0.72 & 4 \\ \text { 2-Acetamido-4-methylsulphinylmethylthiazole (VII) } & 0.54 & 11 \\ \text { 2-Acetamidothiazole-4-carboxylic acid (V) } & 0.32 & 7 \\ \text { Total recovery in 24h urine sample } & & 70\end{array}$

\section{Discussion}

Formation of mercapturic acids from reactive alkyl and aralkyl halides is well known (Bray et al., 1958) so the large proportion of compound (II) formed was expected.

The conversion of the chloromethyl group into a methylthiomethyl group is, we believe, a novel route of metabolism and may proceed from the breakdown of the mercapturic acid. The mercapturic acid (II) is presumably formed by breakdown of the glutathione conjugate (Bray et al., 1959). We were able to demonstrate the formation of the corresponding glutathione conjugate in vitro, by using the soluble fraction of liver homogenate to catalyse the reaction between compound (I) and GSH. No compound (II) was formed in this reaction.

Trace amounts of the glutathione conjugate were formed without the presence of the liver soluble fraction, so it is possible for chemical reaction alone to account for some of the glutathione conjugate formed.

The mercapturic acid (II), however, was not formed either by enzymic or by direct chemical reaction when compound (I) was incubated with $N$-acetyl-L-cysteine, with or without the soluble liver fraction.

The further metabolism of the major metabolite, compound (II), gave the three minor metabolites compounds (III), (VII) and (VIII) identified by their u.v. spectra and $R_{F}$ values (Table 4). The relative proportions of these metabolites in the urine from rats dosed with the mercapturic acid conjugate (II) were very similar to those of the metabolites of the original chloro compound (I) if a correction was applied for the direct hydrolysis of the latter compound.

The occurrence of the methylthio compound (III) as a metabolite of the mercapturic acid was confirmed also by its isolation from urine of rats that had received unlabelled compound (II). The i.r. spectrum of this metabolite was identical with that of an authentic specimen of compound (III).

We could not detect any $S$-glucuronide formation in these experiments, as might be expected if the thiol compound (IV) were an intermediate in the conversion of compound (II) into compound (III).
The formation of thiol compounds during the metabolism of thiazoles may account for some of the actions of thiazole drugs. Thus the generation of the thiourylene grouping $-\mathrm{N}-\mathrm{CS}-\mathrm{N}^{\prime}$ in vivo as a common feature of the metabolism of acetamidothiazoles (Chatfield \& Hunter, 1973) could well explain the anti-thyroid action of such compounds (Bovet $e t$ al., 1946; Liberti \& Stanbury, 1971).

Similarly, the formation of thiol-containing metabolites such as compound (IV), even if only transient, may be significant in the anti-inflammatory action of thiazoles such as compound (I). The thioldisulphide equilibrium during the maintenance and suppression of the inflammatory response has been studied by Butler et al. (1969) and Gerber et al. (1967) have discussed the effect of protein thiol concentrations on the development of arthritic lesions.

The metabolism of other thiazoles that are devoid of anti-inflammatory action may well provide some basis for assessing this hypothesis.

The metabolism of 2-acetamido-4-chloromethylthiazole, which contains the chemically reactive chloromethyl group, shows that the oxidative metabolism of thiazole compounds that we have reported previously can be modified considerably if reactive substituents are present.

We thank the Lilly Research Centre Ltd. for assistance with this work and for permission to publish the results. We also thank Dr. B. Millard of the School of Pharmacy, University of London and Dr. J. Occolowitz of Lilly Research Laboratories, Indianapolis, Ind., U.S.A., for the determination of the mass spectra of metabolites.

\section{References}

Bhargava, P. N. \& Singh, P. R. (1960) J. Indian Chem. Soc. 37, 241-243

Block, R., Durrum, E. \& Zweig, E. (1958) Manual of Paper Chromatography and Paper Electrophoresis, 2nd edn., p. 132, Academic Press, New York, U.S.A.

Bovet, D., Bablet, J. \& Fournel, J. (1946) Ann. Inst. Pasteur 72, 105-125 
Bray, H. G., James, S. P. \& Thorpe, W. V. (1958) Biochem. J. 70, 570-579

Bray, H. G., Franklin, T. J. \& James, S. P. (1959) Biochem. J. 71, 690-696

Butler, M., Giannina, T. \& Steinetz, B. G. (1969) Fed. Proc. Fed. Amer. Soc. Exp. Biol. 28, 357

Chatfield, D. H. \& Hunter, W. H. (1973) Biochem. J. 134, 869-878

Evans, D. (1972) Brit. Patent 1290841
Gerber, D. A., Cohen, N. \& Ginstra, R. (1967) Biochem. Pharmacol. 16, 115-123

Knight, R. H. \& Young, L. (1958) Biochem. J. 70, 111-119 Liberti, P. \& Stanbury, J. B. (1971) Annu. Rev. Pharmacol. 11, 131-135

Thompson, J. F., Arnold, W. N. \& Morris, C. J. (1963) Nature (London) 197, 380-381

Traumann, K. (1960) Justus Liebigs Ann. Chem. 249, 38-42 